\title{
Effects of Biased Media on Foreign Policy Preferences: Evidence from a Natural Experiment
}

\author{
Nora Kirkizh ${ }^{1}$
}

\begin{abstract}
The expansion of globalization has made a country's prosperity increasingly dependant on foreign politics. This article shows how Russian television's inflammatory coverage of European politics affected the vote during the European Union membership referendum in Latvia. For identification, I use plausibly exogenous variation of the signal from Russian analog TV towers that was available during the referendum to Latvian counties located close to the Russian border. The analysis of the electoral data showed that in counties with the Russian television reception, votes "for" outperformed votes "against" joining the European Union compared to counties without the reception. Moreover, the effect of Russian television persisted even in counties densely populated by ethnic Russians. Contrary to previous experimental studies, the evidence suggests that specifically in the context of foreign politics, foreign biased media increase the salience of foreign policy issue but is unable to shift the direction of the public response.
\end{abstract}

\footnotetext{
${ }^{1} \mathrm{PhD}$ student, TU Munich, the School of Governance, and Doctoral Researcher at Department of Computational Social Science, GESIS Leibniz Institute for Social Sciences. E-email: eleonora.kirkiza@tum.de
} 
In a globalized world, countries' foreign policies are becoming ever-more consequential. Membership in trade or military unions can change single-state policies or shake entire economies (e.g. Brexit). In European democracies, the public often decides on country's foreign politics. But if the public does not have entrenched preferences on foreign policies, media becomes one of the primary sources of information to form them. Since the outcome of referenda can be decided by a small voting margin, any misleading information about an international agreement or a union can be costly for the state. This situation can work to the advantage of external actors if the international politics interests of two neighbouring states diverge. One state might find it profitable to alter voters' foreign policy preferences in its "defecting" neighbor. As a result, a nondemocratic state can deploy its soft power by administrating a propaganda campaign to target international institutions or specific foreign policies. For instance, Russian media and propaganda campaigns on Facebook and Twitter sought to influence public opinion over immigration politics in Germany (Elshehawy et al. 2019), European Union policies on trade with Ukraine in the Netherlands ${ }^{2}$, the role of NATO in Sweden ${ }^{3}$ or the independence referendum in Catalonia. ${ }^{4}$ While there is considerable anecdotal evidence addressing the aims and intentions of these campaigns, it is still unclear if Russian media had an effect. This article addresses this question by measuring the effect of Russian analog television on votes in the 2003 European Union membership referendum in Latvia. For identification, I use exogenous variation of Russian analog television signal that was available to Latvian regions close to the Russian border. Contrary to the public debate, the findings indicate that Russian television was countereffective in shaping average Latvians' foreign policy preferences. Contradicting the previous research, although decreased, the effect persisted even among Russian minorities, suggesting that foreign media can increase the salience of foreign policy issue but is unable to shift the direction of the public response.

2 "Fake News, Fake Ukrainians: How a Group of Russians Tilted a Dutch Vote," The New York Times, September 16, 2017.

3 "A Powerful Russian Weapon: The Spread of False Stories," The New York Times, August 28, 2016.

4 "Spain Catalonia: Did Russian 'fake news' stir things up?" BBC, November 18, 2017. 


\section{BACKGROUND}

The case of Russian television in Latvia presents an excellent setting for studying the effects of biased media on foreign policy preferences. First, although national polls were reporting that a majority of the public supported integration into the European Union, the Eastern region of Latvia, Latgale, where ethnic Russians consist of more than 30 percent of population, voted against joining. This opposition emerged despite signaled benefits for the Russian community from entering the $\mathrm{EU}^{5}$ and having no significant economic advantages from living close to Russia. ${ }^{6,7}$ Second, survey evidence shows that before the referendum ethnic Russians and Latvians had similar level of confidence in the European Union (see Political attitudes section in the online appendix). Finally, after Vladimir Putin came to power in 1999, Russian television's coverage of Western European politics grew increasingly unfavorable. Television broadcasting in Russia in 2000s described in the literature as a monopoly of the state and its deferential oligarchs (Colton and McFaul 2006, 217). ${ }^{8}$ In particular, in 2003 Russian television channels devoted substantial coverage to the European Union and Latvian politics. Overall, as expected the coverage of the European Union referendum in Latvia was not as emotionally charged as it could if the news reports were about military conflicts, for instance. Nevertheless, the reports expressed skepticism about the fairness of voting procedures and doubts about the referendum outcome (see the online appendix for content analysis). TV news shows also covered the referendums in other former communist states like Czech Republic, Poland, Lithuania, and Estonia, which ended up joining the union. This could substantially increase the positive salience of the European Union politics.

\footnotetext{
${ }^{5}$ National Harmony Party, that represented Russian population interests in Latvia, supported the referendum hoping that the EU will protect rights of ethnic Russians (Pridham 2003).

${ }^{6}$ Latvian trade with Russia increased after the EU referendum. "Role of Russia in foreign trade of Latvia," Lettia.lv, September 11, 2009.

7 "Coping with Emigration in Baltic and East European Countries," OECD.

${ }^{8}$ Russia was 148th in the Reporters without Borders ranking of press freedom in 2003, down from the 121st place in 2002.
} 


\section{THEORY AND HYPOTHESES}

Previous research shows that cross-national media effects exist: Exposure to German television increased voter turnout in Switzerland (Butler and De La O 2011); Serbian radio induced nationalist behaviour among living in the bordering regions Croatians (DellaVigna et al. 2014), Western television increased public support for the communist regime in East German, and China (Kern and Hainmueller 2009; Huang and Yeh 2017), Russian television polarized Russian and Ukrainian speaking public in Ukraine over presidential and parliamentary elections (Peisakhin and Rozenas 2018). The effects of biased media in the context of foreign politics however remains unclear.

Biased media effects imply several potential mechanisms. The public can observe propaganda and is able to identify facts, or substitute the political content with entertainment (Truex 2016; Durante and Knight 2012). In both scenarios, media effects would be insignificant. Another potential mechanism is that biased messages can be persuasive. However, the evidence demonstrates that vote alteration under the influence of the media is an intricate process that is either negligible or hardly observable (Gerber et al. 2011). Nonetheless, in the case of Russian television in Latvia, biased media effects might be more pronounced because the referendum touched upon a relatively new foreign policy, towards which the public did not yet have entrenched preferences. The issue of the European Union integration in general was not salient in Latvia until three months before the referendum. One more mechanism is that if the message converges with peoples' preexisting dispositions, it can further reinforce existing opinion or prejudice (Zaller 1992; Adena et al. 2015; Kunda 1990; Peisakhin and Rozenas 2018). Specifically, Russian television might be countereffective among average Latvians but influential in Russian communities due to their historical background. ${ }^{9}$ Another mechanism is that Russian communities would support Russia regardless of the political message because Russian

\footnotetext{
${ }^{9}$ After the Soviet Union fall, most of the factories in East Latvia lost their state subsidies. The Eastern region of Latvia still remains one of the poorest regions in the European Union. Hence, Russian communities might still have prejudice against the West because, from their perspective, the West initiated the Latvia's separation from Russia.
} 
culture is culturally closer to them than Baltic or Western one. Thus, relying on the evidence from existing research on reinforcement effects of media by ethnic and historical sentiments, I expect that the exposure to Russian television on average should increase pro-EU votes among Latvians (Hypothesis 1), but should decrease pro-EU votes in the Russian community (Hypothesis 2).

\section{EMPIRICS}

The data includes 226 counties (Latvian: pagasti) that are located within $150 \mathrm{~km}$ from Russia. The data for the outcome variable, the share of votes for joining the European Union in every county, and the location of precincts, are available from the Central Election Commission of Latvia. Almost every county in Latvia has one precinct. In cases where the number of precincts is more than one, I average the result of vote. To estimate the reception of Russian analog TV in every county, I used RadioMobile, a tool for predicting radio and TV wave propagation based on Irregular Terrain Model (ITM) described in Crabtree and Kern (2018). ITM takes into account the power and the frequency of the transmitters, the height above the ground and geographical coordinates of the towers, elevation data and the signal path loss. The signal strength is measured in millidecibels $(\mathrm{dBm})$. I use a standardized form of the signal strength bounded between zero and one (see the online appendix for summary statistics and distributions). The data on the parameters of Russian TV transmitters and towers is available from the International Telecommunication Union (ITU). There were seven Russian analog TV towers along the Latvian-Russian border in 2003. ${ }^{10}$ I utilize the coverage of the two towers with the most powerful transmitters as they cover the largest territory of Latvia. The results indicate that 50 percent of the sampled counties had good reception of Russian television. The maps of precinct location and the estimated television coverage are in the online appendix.

Several variables on economy and demographics are available from the Central Sta-

\footnotetext{
${ }^{10}$ ITU data also showed that the number of Russian TV towers did not change, which signifies of nonstrategic placement of towers on the border with Latvia by the Russian government.
} 
tistical Bureau of Latvia. Demographic controls include the population, the population aged over 60 (the older generation might still have ties to post-Soviet Russia), education,

ethnic groups (percentage of ethnic Latvians, and Russians in a county). Social-economic variables are the unemployment rate and percentage of the working-age population. I also constructed a dummy for the location of large Soviet factories as a proxy for the possible effect of losing jobs due to the closure of main enterprises in the region after the dissolution of the Soviet Union. In addition, I include a dummy to measure if a county contains a large town, or consists of villages only because television consumption tends to be higher in rural areas. I also used Google Maps to measure if a county has railways or main roads on its territory.

To measure the political context, I use the results of a previously held referendum in 1998. The referendum was held to determine whether to increase the number of potential options to obtain a Latvian citizenship by those who were born after the fall of Soviet Union. The referendum also serves as a "placebo" for this study. If the vote in the 1998 referendum does not correlate with the availability of Russian television, we can assume that Russian television effects are related specifically to the EU referendum.

\section{Research design}

I use "encouragement design", implying the availability of the treatment but not the compliance with it (Duflo et al. 2008). The signal strength is a measure of the access to Russian television, not actual consumption. Fine grained individual-level data in Latvian border regions over time is not available hence the news consumption cannot be identified systematically. However, previous studies in a different contexts demonstrate a high correlation between having an access and watching the television (DellaVigna et al. 2014; Peisakhin and Rozenas 2018). I follow these studies to assume similar correlation in the context of Russian television in Latvia.

The Russian television signal is as-if at random if it does not correlate with all possible observables. However, because of relatively flat terrain of Latvian, the signal strength correlates with the distance to Russia. Hence, when testing the independence 
Table 1: Balance tests. OLS coefficients for residualized Russian television reception.

\begin{tabular}{|c|c|c|c|c|c|c|c|}
\hline & \multicolumn{3}{|c|}{ County-level effects } & \multicolumn{3}{|c|}{ District fixed effects } & \multirow[b]{2}{*}{ Obs. } \\
\hline & Est. & S.E. & p-val. & Est. & S.E. & p-val. & \\
\hline \multicolumn{8}{|l|}{ County features } \\
\hline 1. Pro-Russian vote, 1998 & -0.21 & 0.04 & 0.00 & -0.05 & 0.05 & 0.28 & 220 \\
\hline 2. Number of votes, 1998 & 0.38 & 0.23 & 0.10 & 0.13 & 0.27 & 0.63 & 220 \\
\hline 3. \% Ethnic Russians & -0.26 & 0.07 & 0.00 & -0.11 & 0.10 & 0.28 & 220 \\
\hline 4. Population (log) & 0.11 & 0.29 & 0.70 & -0.03 & 0.38 & 0.94 & 220 \\
\hline 5. Rural precinct & 0.01 & 0.11 & 0.94 & 0.08 & 0.14 & 0.55 & 220 \\
\hline 6. Close to highways & 0.27 & 0.19 & 0.16 & 0.32 & 0.24 & 0.19 & 220 \\
\hline 7. Close to railways & -0.09 & 0.08 & 0.28 & -0.09 & 0.09 & 0.34 & 220 \\
\hline 8. Former USSR factory & -0.01 & 0.07 & 0.87 & 0.03 & 0.05 & 0.58 & 220 \\
\hline 9. \% Working age & 0.00 & 0.01 & 0.73 & -0.02 & 0.01 & 0.18 & 220 \\
\hline 10. Age 60 and older & -0.05 & 0.02 & 0.00 & 0.02 & 0.02 & 0.51 & 220 \\
\hline 11. Higher education & 0.00 & 0.01 & 0.65 & -0.01 & 0.01 & 0.34 & 220 \\
\hline 12. \% Unemployed & -0.36 & 0.09 & 0.00 & 0.00 & 0.12 & 0.98 & 220 \\
\hline
\end{tabular}

of the signal from potential confounders, I calibrate the signal strength based on the distance to Russia. Following the specifications from Peisakhin and Rozenas (2018), I use a semiparametric ordinary least squares (OLS) regression model to estimate residualized television reception conditional on the distance to Russia:

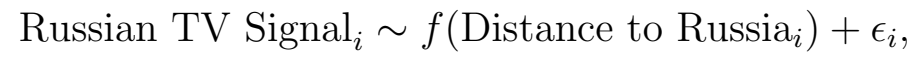

where $f$ is an unknown smooth function approximated by natural cubic splines, which helps to avoid overfitting (Molinari et al. 2004) and $\epsilon_{i}$ is the error term at the county level (number of bootstraps is 1000). I then include the estimated residualized signal strength into every independence test on both a county and district level. All twelve tests are summarised in Table 1. Overall, most observables do not correlate with the Russian television signal but the share of Russian speakers, unemployed, and population of age 60 and older are significantly related to it. The vote in the 1998 referendum also negatively correlates with the signal, implying that Russian television in 2003 could be influencing the Latvian population that was performing pro-Russian political behavior since the 1990s. All covariates with significant correlations, including the vote in 1998, I take into account in the primary regression models. 
Table 2: County-level regression results. Dependent variables are vote-percentages for joining the European Union and turnout. All specifications control for smoothing splines for distance to Russia.

\begin{tabular}{lccccc}
\hline & \multicolumn{2}{c}{ Vote for the EU } & & \multicolumn{2}{c}{ Turnout } \\
\cline { 2 - 3 } \cline { 5 - 6 } & Baseline & Full & & Baseline & Full \\
\hline Russian TV reception quality & $0.45^{* * *}$ & $0.18^{* * *}$ & & $0.16^{*}$ & 0.07 \\
& $(0.07)$ & $(0.05)$ & & $(0.07)$ & $(0.07)$ \\
\% Ethnic Russians & & $-0.53^{* * *}$ & & $-0.21^{* *}$ \\
Pro-Russian vote in 1998 & & $(0.04)$ & & $(0.06)$ \\
& & $-0.43^{* * *}$ & & -0.18 \\
\% Unemployed & & $(0.07)$ & & $(0.09)$ \\
Adjusted $R^{2}$ & & $-0.09^{* *}$ & & 0.05 \\
Observations & 0.16 & $(0.03)$ & & $(0.05)$ \\
\hline
\end{tabular}

Standard errors are in parentheses; ${ }^{*} \mathrm{p}<0.05 ;{ }^{* *} \mathrm{p}<0.01 ;{ }^{* * *} \mathrm{p}<0.001$.

\section{Results}

To estimate the effect of the availability of Russian television on the vote in the European Union membership referendum in Latvia, I used semiparametric OLS regression model similar to the one in equation 1:

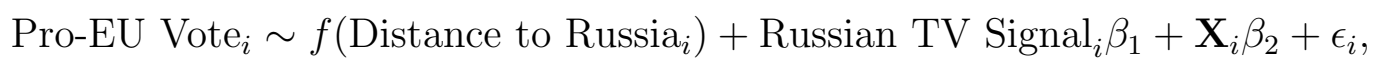

where pro-EU vote is the vote share for joining the EU in a county, Russian TV Signal is the signal strength of Russian television, and $\mathbf{X}_{i}$ is a matrix of control variables.

Table 2 shows that the coefficient for Russian TV signal from the full model is significant at a 99 percent confidence level and positive, which confirms Hypothesis 1. This result implies that the availability of Russian TV was countereffective in persuading an average Latvian to vote against joining the European Union. Substantially, one standard deviation increase in Russian TV reception leads to 1.8 (between 1.3 and 2.3 percentage points) increase in pro-EU vote share. The effect is consistent with the backfire mechanism, suggesting that Russian television content was not in line with predispositions of average Latvian population, which eventually resulted in the increase of the pro-EU vote. 
Table 3: Robustness checks: residualized regression coefficients for Russian TV reception. All specifications include the full set of covariates.

\begin{tabular}{|c|c|c|c|c|c|}
\hline \multirow[b]{2}{*}{ Sample specification } & \multicolumn{2}{|c|}{ Vote for the EU } & \multicolumn{2}{|c|}{ Turnout } & \multirow[b]{2}{*}{ Obs. } \\
\hline & Coef. & S.E. & Coef. & S.E. & \\
\hline 1. Distance to Russia $<50 \mathrm{~km}$ & $0.23^{* *}$ & $(0.07)$ & 0.11 & $(0.10)$ & 93 \\
\hline 2. Distance to Russia $>25 \mathrm{~km}$ & $0.16^{* *}$ & $(0.06)$ & 0.09 & $(0.10)$ & 171 \\
\hline 3. Russian TV reception $\in(0.2,0.8)$ & $0.16^{* *}$ & $(0.05)$ & 0.15 & $(0.09)$ & 177 \\
\hline 4. Only villages & $0.20^{* * *}$ & $(0.05)$ & 0.09 & $(0.07)$ & 200 \\
\hline 5. Only towns and cities & 0.13 & $(0.10)$ & -0.20 & $(0.34)$ & 20 \\
\hline 6. Only Daugavpils city (no signal) & $-0.63^{*}$ & $(0.30)$ & -0.12 & $(0.52)$ & 26 \\
\hline 7. Without Daugavpils city & $0.22^{* * *}$ & $(0.05)$ & 0.06 & $(0.07)$ & 194 \\
\hline 8. Control for $\geq 60$ years olds $(\%)$ & $0.18^{* * *}$ & $(0.05)$ & 0.09 & $(0.07)$ & 220 \\
\hline 9. $\geq 60 \%$ ethnic Russians & 0.04 & $(0.15)$ & $-1.39^{* * *}$ & $(0.28)$ & 14 \\
\hline 10. $<60 \%$ ethnic Russians & $0.14^{*}$ & $(0.06)$ & 0.08 & $(0.09)$ & 206 \\
\hline 11. Control for population N (log) & $0.19^{* * *}$ & $(0.05)$ & 0.08 & $(0.07)$ & 220 \\
\hline 12. Control for higher education $(\%)$ & $0.19^{* * *}$ & $(0.05)$ & 0.06 & $(0.07)$ & 220 \\
\hline
\end{tabular}

Note: Standard errors in parentheses; ${ }^{*} \mathrm{p}<0.05 ;{ }^{* *} \mathrm{p}<0.01 ;{ }^{* * *} \mathrm{p}<0.001$.

Table 2 also shows that the effect of Russian television on turnout. Consistent with Velez and Newman (2019), the effect is not significant, implying that Russian television did not generate new votes.

Robustness. The results are generally robust to different specifications, including samples that consist of counties of various distances from Russia, only rural, and controlling for 60 years olds, which initially correlated with the Russian television signal. The full list of regression results by sample specification is in Table 3. Interestingly, the effect of Russian television disappears in counties where the share of ethnic Russians is equal to or larger than 60 percent, implying that ethnicity did not play a role in the electoral behavior. However, the number of observations is very small, which makes this result unstable and therefore interpretation suggestive. These results contradict the findings from Peisakhin and Rozenas (2018), where Russian television was more effective among Russian-speaking Ukrainians and generated additional pro-Russian votes in presidential and parliamentary elections in Ukraine.

Heterogeneity. I explore the effect heterogeneity by looking at the effect of Russian television conditional on the vote in the 1998 referendum, and the share of ethnic Russians in a county. Following Hainmueller et al. (2019), I use a linear and discreet ap- 


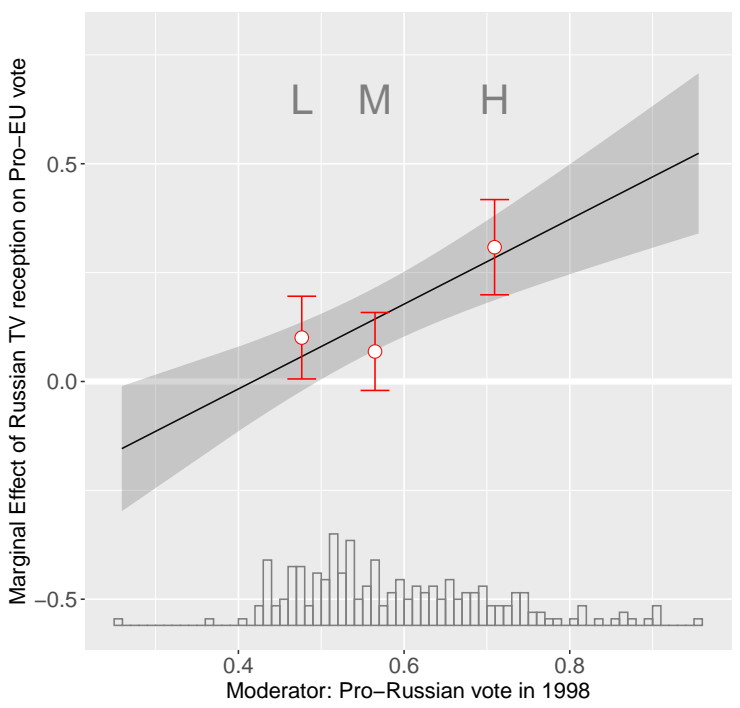

(a)

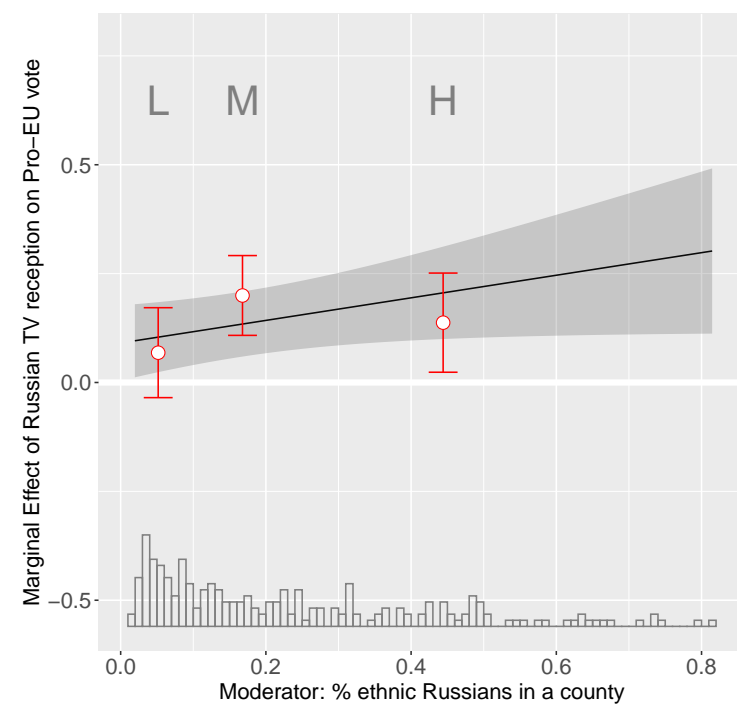

(b)

Figure 1: Marginal effects of Russian television signal on pro-EU vote in the European Union membership referendum in 2003 conditional on (a) pro-Russian vote in the referendum in 1998, and (b) percent of ethnic Russians in a county.

proximation of the conditional effect. In both scenarios, the effect of Russian television on pro-EU vote remains significant and positive. Figure 1a illustrates a consistent increase in the pro-EU vote share conditional on prior voting in 1998. Figure 1a, shows that under linear approximation, the magnitude of Russian television's marginal effect on pro-EU vote depending on share of Russians in a county is significantly lower than depending on prior electoral behavior from Figure 1a, but still significant and positive. Estimation with the variable recorded into low, medium, and high share of Russian speaking population, shows that the effect of Russian television is generally consistent with linear approximation and with the results from robustness checks in Table 3, model nine but not with Hypothesis 2 (regression tables with interaction terms are in the online appendix). In the online appendix, I also report heterogeneity analysis based on the kernel regularized least squares, which estimates the effect of interest depending on every value in the share of ethnic Russians in a county. The effect of Russian television on pro-EU vote remains significant and positive.

In conclusion, electoral effects of Russian television in Latvia in the context of foreign politics reveals the limits of foreign propaganda. Foreign biased media is not able to alter the vote among the population with strong priors. However, the positive effect among 
ethnic minorities is surprising. One potential mechanism of this finding is that the Russian television might have simply increased salience of the European Union referendum but did not change prior preferences within the Russian community. As mentioned in Background section, Russian television channels were reporting about the outcomes of the referenda in other post-communist countries, which were all positive, and ethnic Russians hoped to benefit from joining the European Union because of the institution's protection of minorities' rights.

\section{CONCLUSION}

This article documents the effects of a biased media on foreign policy preferences by examining the case of the European Union membership referendum and Russian television in Latvia. The role of media in the context of geopolitics is crucial because the public usually does not have entrenched preferences over foreign policies. The analysis of the electoral data demonstrates that the availability of a biased media influenced foreign policy preferences of the population in a democratic state in the opposite direction from a potential foreign state interest: On average, Latvian counties with access to Russian television were more likely to vote for joining the EU than the counties without access. The effect persisted even in counties with the large share of the ethnic Russian population, which contradicts the existing debate that ethnic minorities will support their motherland under any circumstances. This evidence suggests that foreign biased media might increase the salience of an issue but leave the public's preferences unaffected. These results have policy implications for democracies on how to counteract biased "foreign voices".

\section{REFERENCES}

Adena, Maja, Ruben Enikolopov, Maria Petrova, Veronica Santarosa, and Ekaterina Zhuravskaya (2015). Radio and the Rise of the Nazis in Prewar Germany. Quarterly Journal of Economics 130(4), 1885-1939.

Butler, Daniel and Ana De La O (2011). The Causal Effect of Media-Driven Political 
Interest on Political Attitudes and Behavior. Quarterly Journal of Political Science 5, $321-337$.

Colton, Timothy and Michael McFaul (2006). Popular Choice and Managed Democracy: The Russian Elections of 1999 and 2000. Washington: Brooking Institution Press.

Crabtree, Charles and Holger L. Kern (2018). Using Electromagnetic Signal Propagation Models for Radio and Television Broadcasts: An Introduction. Political Analysis 26(3), $348-355$.

DellaVigna, Stefano, Ruben Enikolopov, Vera Mironova, Maria Petrova, and Ekaterina Zhuravskaya (2014). Cross-Border Media and Nationalism: Evidence from Serbian Radio in Croatia. American Economic Journal: Applied Economics 6(3), 103-132.

Duflo, Esther, Rachel Glennerster, and Michael Kremer (2008). Using Randomization in Development Economics Research: A Toolkit. In T. Paul Schultz and John Strauss (Eds.), Handbook of Development Economics, Volume 4. Amsterdam and New York: North Holland: Elsevier.

Durante, Ruben and Brian Knight (2012). Partisan Control, Media Bias, and Viewer Responses: Evidence from Berlusconi's Italy. Journal of Public Economics 10(3), $451-481$.

Elshehawy, Ashrakat, Nikolay Marinov, Federico Nanni, and Harald Schoen (2019, July). Who Wants to Talk about Refugees and Why? Foreign Interventions in German Elections. Working Paper.

Gerber, Alan S., James G. Gimpel, Donald P. Green, and Daron R. Shaw (2011). How Large and Long-Lasting Are the Persuasive Effects of Televised Campaign Ads? Results from a Randomized Experiment. American Political Science Review 105(1), 135-150.

Hainmueller, Jens, Jonathan Mummolo, and Yiqing Xu (2019). How Much Should We Trust Estimates from Multiplicative Interaction Models? Simple Tools to Improve Empirical Practice. Political Analysis 27(2), 163-192. 
Huang, Haifeng and Yao-Yuan Yeh (2017). Information from Abroad: Foreign Media, Selective Exposure, and Political Support in China. British Journal of Political Science, 1-26. https://doi-org.ezproxy.cul.columbia.edu/10.1017/S0007123416000739.

Kern, Holger Lutz and Jens Hainmueller (2009). Opium for the Masses: How Foreign Media Can Stabilize Authoritarian Regimes. Political Analysis 17, 377-39.

Kunda, Ziva (1990). The Case for Motivated Reasoning. Psychological Bulletin 108(3), 480-498.

Molinari, Nicolas, Jean-François Durand, and Robert Sabatier (2004). Bounded Optimal Knots for Regression Splines. Computational Statistics 8 Data Analysis 45(2), $159-178$.

Peisakhin, Leonid and Arturas Rozenas (2018). Electoral Effects of Biased Media: Russian Television in Ukraine. American Journal of Political Science 62(3), 535-550.

Pridham, Geoffrey (2003, September 20). Referendum Briefing No 10 Latvia's EU Accession Referendum. Technical Report 10, European Parties Elections and Referendums Network, Brighton, UK.

Truex, Rory (2016). Bias and Trust in Authoritarian Media. Working Paper, Available at SSRN: https://ssrn.com/abstract $=2802841$.

Velez, Yamil Ricardo and Benjamin J. Newman (2019). Tuning In, Not Turning Out: Evaluating the Impact of Ethnic Television on Political Participation. American Journal of Political Science 63(4), 808-823.

Zaller, John (1992). The Nature and Origins of Mass Opinion. NY: Cambridge University Press. 